\title{
Critical Discourse Analysis of the Political Speech of the Egyptian President, Abdel Fattah El-Sisi, at the New Suez Canal Inauguration Ceremony
}

\author{
Dr. Inas Hussein Hassan \\ Lecturer, Institute for Language Studies \\ Vice Dean for Postgraduate Studies, \\ Arab Academy for Science, Technology and Maritime Transport
}

\begin{abstract}
This paper focuses on employing Critical Discourse Analysis (CDA) in studying Arabic political discourse. The objective of the study was to explore the intended ideologies and the critical linguistic aspects in the political speech delivered by the Egyptian President, Abdel Fattah El-Sisi, at the New Suez Canal inauguration ceremony on $6^{\text {th }}$ August, 2015. The paper put these themes in their social and cultural contexts, with a focus on the lexicon used. The speech has been taken from the Internet. In order to achieve the main goal of the study, CDA was used as a theoretical framework to analyze the speech. The analysis of the obtained data was conducted by drawing upon Fairclough's three-dimensional model of CDA; namely, the language text, whether spoken or written, discourse practice and socio-cultural practices. Both macro analysis (semantic macrostructures) and micro analysis (local semantics) were conducted in an attempt to link social and linguistic practices. The results of the study revealed that this speech has its distinctive features and that language was used tactfully to arrive at the intended goals of the speaker. Semantic phenomena such as figures of speech, repetition, synonymy and collocation are widely employed in the speech of the Egyptian president to achieve different political ideologies.
\end{abstract}

Key words: Critical Discourse Analysis, Political Discourse Analysis, New Suez Canal inauguration, ideologies, semantic macrostructures, local semantics.

\section{Introduction}

Before we embark on an analysis of the speech of the Egyptian President, Abdel Fattah El-Sisi, at the New Suez Canal inauguration ceremony held on $6^{\text {th }}$ August, 2015 , it would be useful to give a brief background on such a significant event in order to contextualize his speech.

On $6^{\text {th }}$ August, 2015, Egypt inaugurated the New Suez Canal Project. The Egyptian President, Abdel Fattah El-Sisi, headed the ceremony that was attended by prominent international figures including French President Francois Hollande, Kings of Jordan and Bahrain and the Russian Prime Minister. The inauguration ceremony began with El-Sisi leading the naval procession. Newly acquired French Rafale warplanes and US F-16s participated in the fly-past. Banners saying "New Suez Canal: Egypt's Gift to the World" and "The Egyptian Miracle" as well as hundred of Egyptian flags filled the 
streets of Cairo and Ismailiya. In addition, a crowd gathered at Cairo's Tahrir Squarethe epicenter of protests that ousted Morsi and his predecessor Mubarak.

The project, largely funded by the Egyptian people, was supposed to take three years but under pressure from President El-Sisi, the project was completed in only a year. The new Suez Canal project adds a 35-kilometre shipping lane to the existing canal channel linking the Red and Mediterranean seas. The new canal and by-passers are 72 $\mathrm{km}$ long and stand parallel to the old one. It aims to double Suez Canal revenues by 2023 to be the fastest trade route between the east and the west. The project was highly celebrated as a national achievement having been described as "Egypt's gift to the world" while the inauguration ceremony was seen by many critics as an attempt to improve Egypt's image internationally.

This study investigates the political speech delivered by the Egyptian President, Abdel Fattah El-Sisi, at the inauguration ceremony of the New Suez Canal. Many researchers have investigated political speeches from different perspectives and during crucial points of time, but this study investigates a political speech delivered on a very significant event for Egypt and the Egyptians.

In this study political discourse is analyzed from a linguistic point of view. It is an exercise on how language is used tactfully to arrive at the intended goals of the speaker. The study seeks to analyze an authentic Arabic-language text using the CDA approach as presented in Norman Fairclough's 1992 publication Discourse and Social Change. The analysis will examine the structure, the substance as well as the language of El-Sisi's speech. Several levels will be observed: semantic macrostructures (topics), local meanings and lexical style in order to explain to what extent the speaker's ideologies are reflected in their linguistic choices.

The paper is structured as follows: the first part is theoretical. It gives a necessary skeletal account of CDA, main features of political discourse and basic tenets of Fairclough's model. The second part is methodological. It sketches out a critical approach to discourse analysis. The third part presents the main findings of the study. Finally, the last part outlines conclusions and some recommendations.

\section{Theoretical Underpinnings}

\subsection{Discourse}

Discourse is a broad term with various definitions which integrates meanings ranging from linguistics through philosophy, sociology and other disciplines. Van Dijk (1977) views discourse as text in context, as "data that is liable for empiric analysis" with a focus on discourse as action and process. It follows that "discourse" is a wider term than "text". According to Fairclough (1989, p. 24), discourse is "the whole process of social interaction of which a text is just a part". It can be concluded that discourse refers to verbal communication in its situational and social context. 
It is essential to distinguish two terms: discourse and text. Discourse refers to any natural language representing complete semantic in a certain context. It can be seen and observed in the use of spoken, written and signed language and multimodal forms of communication. According to Halliday and Hassan (1976), a text is "any passage, spoken or written, of whatever length." A distinction is often made between "global" structures such as overall topics and the schematic organizations of discourses and conversations and "local" structures such as relations among sentences, propositions or turns.

Spoken discourse, including political discourse, is usually delivered by an effective speaker. Effective speakers are characterized by a number of advantages: voice quality effects, facial expressions and postural or gestural system. Spoken discourse is more demanding on the speakers than written discourse. Not only is it spontaneous but speakers should monitor what they have just said and plan their next utterances. In addition, speakers need to observe their interlocutors, modify their speech in an acceptable way and monitor their listeners' reactions. Brown and Yule (1983, p. 17) provide the following features that characterize spoken discourse:

1. The syntax of spoken language is less structured than that of written language; it sometimes contains incomplete sentences or phrases and little subordination.

2. There is a little use of pre-modified adjectives.

3. It is quite common to find what is called topic-comment structure.

4. There is a little use of passive construction.

5. The speaker may rely on the immediate environment.

6. The speaker may replace or refine expressions.

7. The speaker uses a good deal of generalized vocabularies such as: a lot of, do, stuff, things, and like.

8. The speaker repeats the same syntactic structure several times.

9. The speaker may produce a large number of prefabricated fillers such as: I think, you know, I'm sure, and of course.

10. Spoken language may contain features such as hesitation, slips and repetitions.

Discourse analysis (DA) is a general term for a number of approaches to analyzing spoken or written language use. The objects of DA are defined in terms of coherent sequences of sentences, propositions, speech acts or turns-at-talk. With regard to this field, though there are various perspectives and approaches that emphasize different aspects of language use, they all view language as social interaction and are usually concerned with the social contexts in which discourse is embedded.

\subsection{Critical Discourse Analysis}

CDA is based on Halliday's Systemic Functional Linguistics (Fairclough, 1992, Fairclough, 1999) and the Critical Linguistics approach which stemmed from the work led by Roger Fowler at the University of East Anglia in the 1970's. Both Halliday's Systemic Functional Linguistics and Critical Linguistics rejected two 
widespread notions in linguistics at that time: the treatment of language systems as autonomous and independent of the use of language, and the separation of meaning from style or expression (Fairclough, 1992).

CDA is an approach to language analysis which is concerned with issues of language, power and ideology. CDA is neither a homogenous model nor a school or a paradigm, but mostly a shared perspective on doing linguistics, semiotic or discourse analysis (van Dijk, 1993). Being an interdisciplinary approach to discourse, it does not consider language as independent from social studies; rather, it focuses on language as a form of social practice (Fairclough and Wodak, 1997). The aim of CDA is to perceive language use as social practice. Language users do not function in isolation; rather they function in a set of cultural, social and psychological frameworks. CDA explores not only the connections between textual structures but also the links between textual structures and their function in interaction with the society.

Therefore, it could be assumed that the one element of CDA which differentiates it from other forms of DA exists in its attribute of "critical". "Critical" implies showing connections and causes which are hidden (Fairclough, 1992). It is important to expose the hidden things since these are not evident for the individuals involved; hence, they cannot be fought against.

\subsection{Fairclough's model}

According to Norman Fairclough, one of the prominent theoreticians who contributed many articles and books that establish CDA as a field of research, there are three levels of discourse: firstly, social conditions of production and interpretation, i.e. the social factors that led or contributed to the origination of a text and, at the same time, would affect the interpretation of the text; Secondly, the process of production and interpretation, i.e. in what way the text was produced and how this affects interpretation; thirdly, the text which is the product of the first two stages.

The analysis of a specific discourse requires analysis in each of these three dimensions and their interrelations. It is hypothesized that significant connections exist between features of texts, ways in which texts are put together and interpreted and the nature of the social practice. In other words, when we interpret a text, we should analyze and understand the social and the discourse practices to reach a full understanding of the analyzed text. CDA is essential in analyzing political texts. When we conduct CDA, it is important to understand the social and historical factors around the text production (van Dijk, 1995). This paves the way for a better understanding of the analyzed text.

In accordance with these three levels of discourse, Fairclough presents three stages of CDA:

- Description which is the stage concerned with the formal properties of the text. 
- Interpretation which is the stage concerned with the relationship between text and interaction- with seeing the text as a process of production and as a resource in the process of interpretation.

- Explanation which is the stage concerned with the relationship between interaction and social context- with the social determination of the processes of production and interpretation and their social effect.

Though Fairclough supported the ideas of Critical Linguistics, he felt that they did not go far enough. He believed that Critical Linguistics focused exclusively on the text as a product and excluded how these texts are produced or how they may be interpreted. Fairclough believes that it is equally essential for us to understand the processes of text production and interpretation. We must also understand the social context in which all these processes occur: "CDA gives attention to the dynamic interplay between text production, the text itself, and text interpretation or consumption" (Fairclough, 1992, p. 5). Fairclough calls this multidimensional approach his 'social theory of discourse'. He called for greater critical analysis of all forms of discourse.

This can be represented diagrammatically as follows:

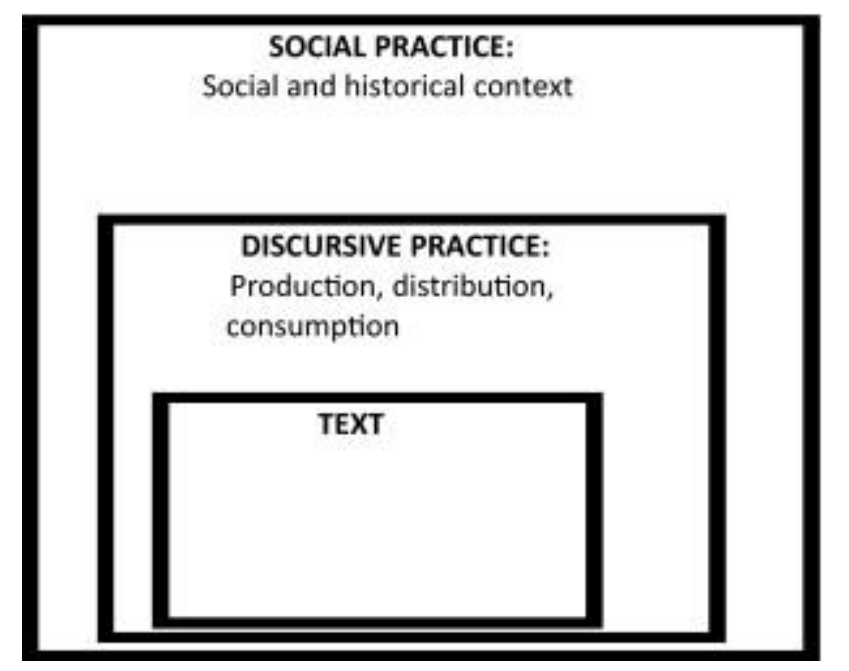

(reproduced from Fairclough, 1992, p. 73)

Fairclough describes this framework as "an attempt to bring together three analytical traditions, each of which is indispensable for discourse analysis". These analytical traditions are:

- The tradition of close textual and linguistic analysis within linguistics

- The macrosociological tradition of analysing social practice in relation to social structures.

- The interpretivist or microsociological tradition of seeing social practice as something which people actively produce and make sense of on the basis of shared commonsense procedures

(adapted from Fairclough, 1992, p. 72) 
Since the three dimensions of this framework considerably overlap in reality, Fairclough (1992) anticipates a number of problems. One problem is the designation of analytical topics as one or the other. This would be largely imprecise. Another problem is the overwhelming number of textual features that are worthy of inclusion in any critical discourse analysis.

\subsection{Political Discourse Analysis}

Since this study aims at analyzing a speech of a political nature, it is necessary to introduce the definition of political discourse and how political speeches and texts can be analyzed.

Political discourse can generally be defined as the written or spoken language, verbal or non-verbal, used in politics to affect the attitudes and opinions of a certain audience. It is distinguished from other types of discourse because it is directive to a certain group, functional, well-organized and rich in figurative language, i.e. metaphors and similes.

Political discourse plays an essential role in shaping people's thoughts and attitudes. Politicians normally function their rhetorical skills in order to change and control people's thoughts and attitudes. To be a successful politician, one should be an eloquent orator in order to steer the receivers' emotions, attentions and minds. Politics can be viewed as "a struggle between those who seek to assert and maintain their power and those who seek to resist it" (Chilton, 2004, p. 3). Therefore, there is a strong relationship between language and political activity (Chilton, 2004).

Political discourse is "a complex form of social activity" (Chilton and Schaffner, 1997, p. 207). Political discourse is so common in the world in general and in the Middle East in particular because it is a conflict area that witnessed the Arab Spring movement that has reshaped different political regimes in the Arab world. Therefore, studying political discourse at this critical moment has been crucial because it contributes to better understanding of the current political situation in the Middle East.

Political Discourse Analysis focuses on the analysis of political discourse. In the light of contemporary approaches to CDA, critical-political discourse analysis deals specifically with the reproduction of political power, power abuse or domination through political discourse. Such an analysis would deal with the discursive conditions and consequences of social and political inequality that result from such domination. In addition, political discourse is not a genre, but a class of genres defined by a social domain, namely that of politics. Therefore, parliamentary debates, party programmes and speeches by politicians are among the genres that belong to the domain of politics (van Dijk, 1998). 


\section{Review of Related Literature}

A number of studies investigating the political speeches of Arab presidents using CDA tenets and tools were recently carried out.

El Mustapha Lahlali (2012) examines the ideological function of lexical repetition in Hassan Nasrallah's speeches. The author argues that little or no focus has been placed on the relationship between repetition and ideology. The findings of the study have shown that repetition has been deliberately used to reinforce Nasrallah's different political strategies which have been devised to address various Lebanese groups and that the prevalence of lexical repetition has been deliberately employed in Nasrallah's speeches to promote his ideological and political stance.

Ahmad Al-Harahsheh (2013) focuses on employing CDA in studying Arabic political discourse in general and the translatability of figures of speech of Khalid Mashaal's political speeches in particular. Three of Mashaal's political speeches were translated into English. CDA was used as a theoretical framework to analyze these speeches. This paper has given support to the notion that linguistic theory and CDA are useful in studying the translation of political discourse. The findings of this study have shown that these speeches are full of figures of speech and the translatability of these figures of speech into English is problematic because the translated version lost the flavor of emotiveness that the original text had. The researcher has suggested some strategies for translators to overcome these obstacles in translation.

Abu Hattab (2013) investigates the changing identities of four Arab Spring presidents: Zain Al-Abedeen, Mubarak, Saleh and Qathafi. The study is tracing how different identities of these leaders were established and is, furthermore, analyzing the linguistic resources utilized to establish them. The findings of the study have revealed that there was a drastic change from semi-god leaders to those ones who were dying to regain public support. The change was mainly reflected through the use of personal pronouns, lexical repetition and in addition, the use of colloquial Arabic.

The aim of a study conducted by Fawwaz Al-Haq and Nazek Al-Sleibi (2015) was to determine the main linguistic strategies that King Abdullah II uses in his speeches. The researchers selected three speeches to be the data of the study. A two-level analysis was conducted in an integrated manner. At the first level, the three speeches were investigated applying the main principles of Critical Discourse Analysis (CDA) which are the description of the text, discourse-as-discursive practice and discourseas-social practice. At the second level, in order to determine how King Abdullah II frames the core issue in his speeches, four persuasive strategies were employed: creativity, reference, circumlocution and intertextuality. The findings of the study have shown that King Abdullah II employs these strategies competently to deliver his messages. The researchers have recommended applying other strategies of political discourse analysis to King Abdullah's speeches: indirectness, euphemism, disclaimers, etc. 
Al Majali (2015) explores the linguistic features of the political speeches of the ousted Arab presidents during the Arab Spring Revolution. The sample of the study is composed of seven speeches delivered by the Tunisian president Zain Al-Abedeen Bin Ali, the Egyptian president Hosni Mubarak and the Libyan president Muammer Al-Gaddafi during the period from December 2010 to December 2012. The analysis of the obtained data is conducted using Halliday and Hassan's (1976) framework of cohesion. The results of the study have shown that these political speeches which were delivered during the Arab Spring Revolution have their distinctive features which are different from the usual speeches of these presidents during normal circumstances. Lexical features such as repetition, synonymy and hyponymy are widely used in these speeches to achieve different political ideologies and strategies.

\section{Statement of the Problem}

Through surveying the related literature, it has been evident that there is no single study that has conducted the task of analyzing the speeches delivered by President ElSisi by adopting the main principles of CDA and examining the linguistic aspects employed by the President to get his audience believe in his ideas. In general, the main problem of this study is to analyze one of the speeches delivered by President El-Sisi in terms of the main tenets of CDA, taking into consideration that these speeches have not received any linguistic attention.

This study investigates the political speech of the Egyptian President on a very significant occasion. The study is the first of its kind since it is an attempt to explore the salient linguistic features of the speech and the main ideologies and strategies used to achieve his long-standing political goals.

\section{Research Objectives}

The research attempts to reveal the main intended ideologies which exist in the speech under investigation. Furthermore, this research highlights the stylistic techniques employed by the Egyptian President in one of his formal speeches. Therefore, the current work has the following objectives:

1. Revealing the main intended ideologies found in the speech

2. Analyzing the critical linguistic aspects of the speech delivered by the President within the main tenets and principles of CDA in order to show how the President wants to get the addressees to believe in his ideas

The study purports to answer the following questions:

1. What are the key intended ideologies involved and enhanced in El-Sisi's speech?

2. What are the strategies and the distinctive linguistic features adopted by the speaker to convince his audience to believe in his ideas? 


\section{Methodology}

In this study the methodological framework was based upon CDA as conceived by one of its most outstanding theoreticians Norman Fairclough (1992, 1995, 2001, 2003). The researcher drew upon the multidimensional model of analyzing discourse developed by Fairclough (1992). Fairclough explains that discourse can be seen as i) a language text, i.e. spoken or written, ii) discourse practices (text production and text consumption), iii) socio-cultural practices. Fairclough (1999) develops the following method of discourse analysis which includes: a) linguistic description of the language text, b) interpretation of the relationship between discursive processes and the text, and c) explanation of the relationship between the discursive processes and social processes.

Procedures of analyzing the data were as follows: first, the speech in its original Arabic version as well as its translated English version was downloaded from the internet. Second, the speech was analyzed in the light of Fairclough's model. There was an attempt to link linguistic practices with socio-cultural practices. Both macro and microanalysis were conducted. The political speech under investigation was then analyzed in terms of semantic macro structures (topics) and local semantics (local meanings). While the first level portrayed the main topics that resided in the speech, the second level tackled the major critical linguistic aspects of the speech: intertextuality of text, religious expressions, figures of speech (metaphor, simile, personification and dysphemism), repetition, synonymy and collocation.

\section{Analysis and Discussion}

\subsection{Social and discursive practices}

The analysis of a discursive event as social practice refers to several levels of social organization, i.e., "the context of situation, the institutional context and the wider social context" (Fairclough, 1992, p. 134). Interdiscursivity is a key concept in analyzing a text because it emphasizes a historical view of texts as transforming the past, e.g. prior texts, into the present. Therefore, it is important to give a historical background about the situation in Egypt during this significant event.

Encouraged by the protests that overthrew the president of Tunisia, Egyptians launched huge anti-government demonstrations in January 2011. These eventually ended President Mubarak's long rule. Following a rule of military rule, the first presidential elections were won by the candidate of Islamist Muslim Brotherhood, Mohammed Morsi, in 2012. However, growing dismay at the government's actions among many Egyptians - primarily secularists, liberals and Coptic Christians - boiled over in another wave of protests. Siding with the demonstrators, the military ousted President Morsi. The new authorities outlawed the Brotherhood and started drafting a new constitution. The army chief, Abdel Fattah El-Sisi, won the presidency in May 2014 elections. 
"By restoring political stability and security in Egypt, Sisi has performed economic miracles in no time," said Salwa al-Antary, an economic analyst and the former head of the research department at the National Bank of Egypt. Sisi "introduced many reforms that helped the economy reach spectacular numbers that haven't been seen since the beginning of the political crisis in 2011," Antary said. She added that by setting deadlines for various projects, Sisi had helped ensure concrete economic advances. Egypt also raised taxes and slashed energy subsidies that have long weighed on state finances. Ambitious projects have been announced, including an $\$ 8.5$ billion plan to upgrade the Suez Canal, a symbol of national pride. Analysts asserted that the assistance of influential business figures has played a key role in the recovery.

In August 2014, President El-Sisi initiated a new Suez Canal which would double the capacity of the existing canal from 49 to 97 ships a day. The project was expected to cost around 60 billion Egyptian pound and would be fast-tracked over a year. El-Sisi insisted that funding should come from Egyptian sources only. El-Sisi also introduced the Sue Canal Development Project which would involve the development of five new seaports in the three provinces surrounding the canal, a new industrial zone west of the Gulf of Suez, economic zones around the waterway, seven new tunnels between Sinai and the Egyptian homeland, building a new Ismailia city, huge fish farms and a technology valley within Ismailia.

As for the discursive practice, the speaker produces the political speech under investigation in real time in front of his audience. The speaker delivered his speech on August $6^{\text {th }}$ At the inauguration, El-Sisi welcomed foreign leaders aboard a historic yacht as helicopters and fighter jets flew by. At the inauguration ceremony in the town of Ismailia, the president appeared in military uniform and sunglasses aboard ElMahrousa - the yacht that was the first vessel to pass through the canal when it was built in 1869. El-Sisi welcomed foreign guests including the French President Francois Hollande and the Russian Prime Minister Dmitry Medvedev. Fighter jets and helicopters flew above the ceremony. In Cairo streets, banners described the expanded canal as Egypt's "gift to the world". Pro-government media have hailed the expansion of the canal as a national triumph and as a turning point after years of instability.

The Egyptian government hopes the revenues will revive the economy- but analysts have questioned the projections. They have pointed out that the volume of world trade has not been growing at the pace needed to deliver the sums Egypt hopes to collect. Egyptians were divided over the project with many asking whether the $\$ 8.2 \mathrm{bn}$ spent on the expansion could have been better deployed on improving infrastructure and public services.

However, many analysts doubted if the new venture would deliver the anticipated benefits. Ahmed Kamaly, an economist at the American University in Cairo, told Reuter news agency that the Egyptian projections were "wishful thinking". He added that the immediate benefits from the expansion were likely to be political than economic, uniting people "around a national project". 


\subsection{Linguistic practices}

A two-level analysis of the political speech under investigation in this study was conducted in an integrated manner: macro analysis in terms of topics and micro analysis in terms of the salient linguistic features of the political speech. The analysis examined the structure, the substance as well as the language of the speech. This section presents the major findings of the study in each of these levels.

\subsubsection{Ideological Analysis: Semantic macrostructures}

Through this political speech, a number of important messages were sent to Egyptians and to the whole world. These are outlined as follows:

Table 1. Macrostructures in El-Sisi's political speech

\begin{tabular}{|ll|}
\hline 1. & Welcoming \\
\hline 2. & Declaration of Strength and Challenging \\
\hline 3. & Thanking \\
\hline 4. & Declaration of Confrontation \\
\hline 5. & Expressing Self-confidence \\
\hline 6. & Announcing the Opening of the New Suez Canal \\
\hline
\end{tabular}

\section{Welcoming}

The first message delivered by the Egyptian President is welcoming the guests who came to join the Egyptians in their joy at this great accomplishment:

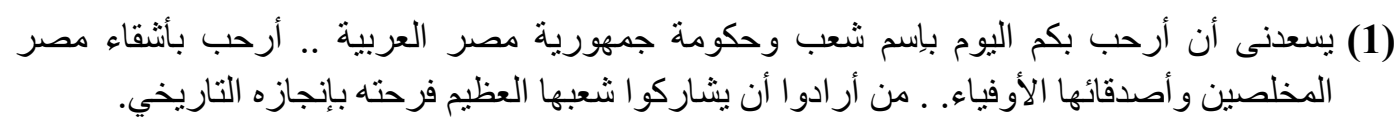

(1) It is my pleasure to welcome you today in the name of the people and government of the Arab Republic of Egypt. I welcome Egypt's loyal friends, who want to join its great people in their joy at this momentous accomplishment.

\section{Declaration of Strength and Challenging}

This second message which is the declaration of strength and challenging is best represented in the following:

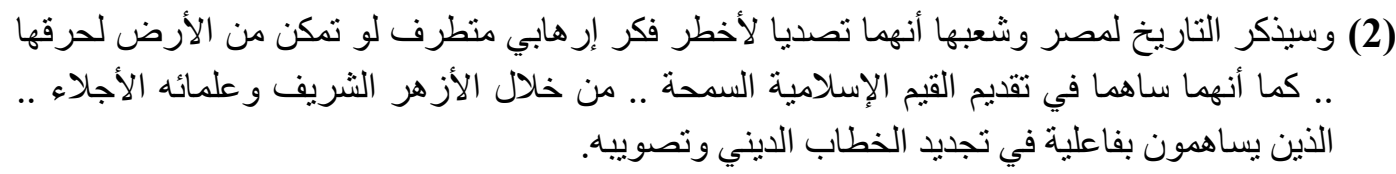

(2) History will judge that Egypt and its people confronted the most dangerous, extremist, terrorist thinking, which, had it prevailed, would have set the world ablaze. Egypt and its people also contributed by promoting the tolerant values 
of Islam through Al Azhar and its honorable scholars, who actively contributed in renewing the religious discourse and rectifying it.
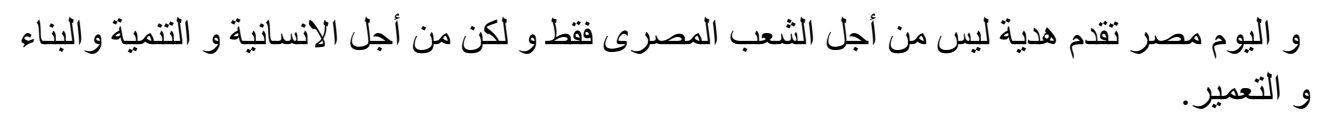

(3) And today Egypt presents its gift to the world for the sake of humanity, reconstruction and development.

\section{Thanking}

The third message, which is expressing gratitude and appreciation to all those who contributed to the completion of this great project meeting the deadline set, is represented in a number of extracts as follows:

$$
\begin{aligned}
& \text { (4) ولن يفوتني فى هذا المقام أن أقدم الثكر لأرواح شهداء مصر الذين جادوا بأنفسهم ودمائهم من أجل ألقا }
\end{aligned}
$$

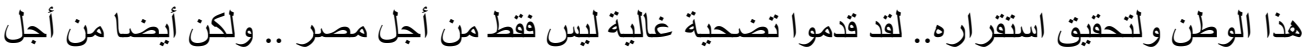

$$
\begin{aligned}
& \text { الإنسانية. }
\end{aligned}
$$

(4) I owe a debt of gratitude to Egypt's fallen heroes who have made the ultimate sacrifice for their homeland in order to establish stability. Their sacrifice is not only for Egypt, but for all humanity.

$$
\begin{aligned}
& \text { كما أتقدم بو افر الثكر و التقدير للهيئة الهندية للقوات المسلحة ولهيئة قناة السويس وتحالف شركات } \\
& \text { التكريك وشركات المقاو لات .. الذين ساهمو ا جميعاً في إنجاز هذا المشروع العزئ العظيم في توقيته المحدد. }
\end{aligned}
$$

(5) I would also like to offer my gratitude and appreciation to the Engineering Authority of the armed forces, the Suez Canal Authority and the consortium of dredging and construction companies, which all contributed to the completion of this project by the deadline that was set.

$$
\text { مصر من أبنائها المخلصين لا أوجها إعزب أبداً. }
$$

(6) Allow me to send a message of appreciation to the people of my country, who proved day after day that Egypt will never cease to raise new generations of loyal citizens.

$$
\text { تحقيق هذا الإنجاز المبهر. المقام أن أنتوجه بخالص الثنكر و التقدير .. لكل من ساهم بنتاج عقله وجهده فى }
$$

(7) I owe my gratitude and appreciation to all those who contributed with their creative ideas and hard work to this amazing achievement. 


\section{Declaration of Confrontation}

Another message conveyed by the speech is the declaration of confronting terrorist groups. El-Sisi emphasized that the Egyptians were facing terrorism while accomplishing this great enterprise:

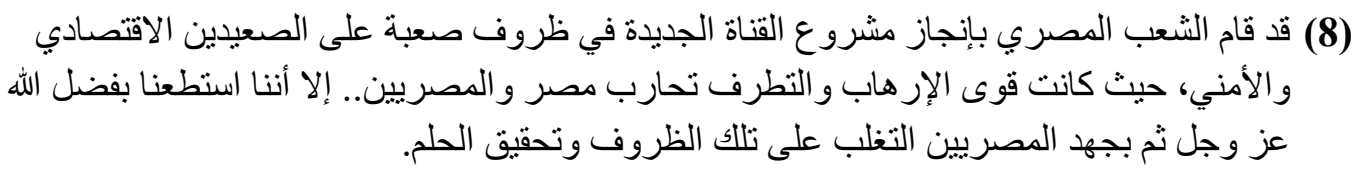

(8) The Egyptian people completed the New Suez Canal under the most difficult circumstances economically and in terms of security. The powers of terrorism and extremism were at war with Egypt and the Egyptians. Yet we were able with God's blessing and with the efforts of the Egyptian people to triumph and realize our dream.

\section{Emphasizing Self-confidence}

Another message delivered by El-Sisi is emphasizing self-confidence. The inauguration of the New Suez Canal has given confidence to the Egyptian people and has demonstrated to the whole world that the Egyptians are capable of accomplishing. $\mathrm{He}$ asserts that this project is the first in a number of projects. This message is clearly reflected in several extracts:

$$
\begin{aligned}
& \text { (إن عظمة القناة الجديدة لا تكمن فقط في كونها إنجاز اً هندسياً هائلاً .. ولكنها أيضا منحت المصربين }
\end{aligned}
$$

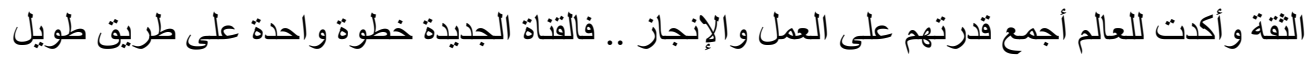

$$
\begin{aligned}
& \text { بدأه المصريون لتحقيق آمالهم وطمو حاتهم. }
\end{aligned}
$$

(9) The splendor of this new canal not only represents a formidable feat of engineering, but has also given the Egyptian people confidence and demonstrated to the entire world what they are capable of accomplishing. The new canal is one step on a long road the Egyptian people have embarked on to realize their aspirations and ambitions.

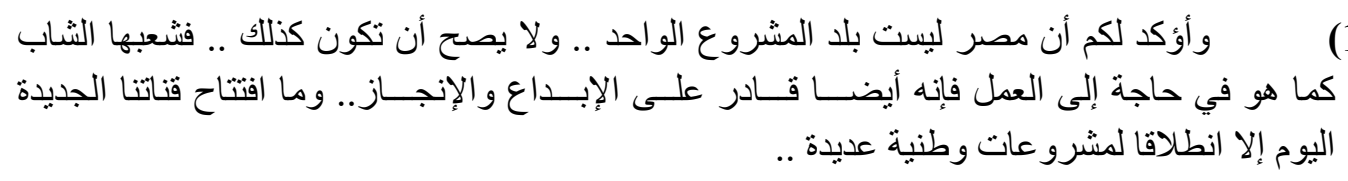

(10)

Let me make clear that Egypt is not and will never be a one-project nation. As our young population seeks work, it is also capable of creativity and accomplishment. The inauguration of the new canal today is just the first in a number of national projects.

$$
\begin{aligned}
& \text { إن مصر التي استعادت إر ادتها مع ثورتي الخامس و العشرين من يناير و الثناثين من يونيو . . } \\
& \text { قد اختارت سبيلها .. و أنارت دربها .. و إن كانت لم تصل بعد إلى كل ما نريد.. فإنها عرفت كل ما تريد }
\end{aligned}
$$


والقادرة على في طريقها لتحقيقه.. و إذا كانت الثعوب قادرة على الحلم .. فإن الشعوب الحرة فقط هي

(11) Egypt, which has restored its will with the January 25 and June 30 revolutions, has chosen its path and illuminated its way forward. Although it has not yet accomplished all it has set out to do, it knows what it wants and is moving forward to realize it. If peoples have the ability to dream, then only free people have the ability to achieve.

\section{Announcing the Opening of the New Suez Canal}

Finally, El-Sisi announced the official opening of the New Suez Canal:

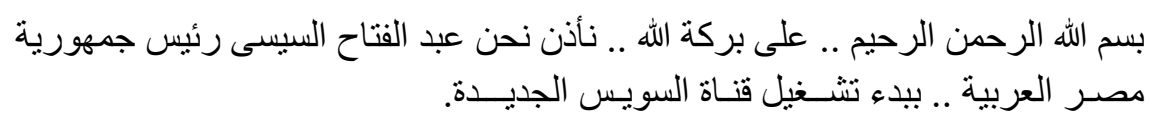

(12) By the blessings of God, I, Abdel Fattah El Sisi, the President of the Arab Republic of Egypt, officially open the New Suez Canal.

Information emphasized as the most important in the speech is expressed in topics or semantic macrostructures and many of them are worded with a view to positively representing the speaker and negatively the opponent. In these macrostructures we can find ideological perspectives which shape the coherence of the speech. Whereas cohesion refers to the overt semantic relations in a text, coherence refers to semantic and pragmatic relations between parts of a text which can be interpretable against the background of specific world knowledge.

\subsubsection{Local Semantics (local meanings): Strategies and linguistic features}

Most ideological beliefs can usually be found in local meanings since they are under the control of the speaker who chooses what propositions and lexical content will be presented to the audience. The positive self-representation and negative otherrepresentation are achieved mostly through lexicalization.

This section tackles the critical linguistic part of the study. Analyzing El-Sisi's speech, the most distinguished features can be shown in intertextuality of text, religious expressions, figures of speech, repetition, synonymy and collocation.

\subsubsection{Intertextuality of Text}

Intertextuality is one of the important political communicative strategies. It involves borrowing from previous texts in creating a new one. Intertextuality is a very persuasive strategy to get the listeners consider what the speaker says. 
El-Sisi's use of intertexuality can be recognized as a purposeful use. This claim would be validated through the following direct borrowing used by El-Sisi in his speech:

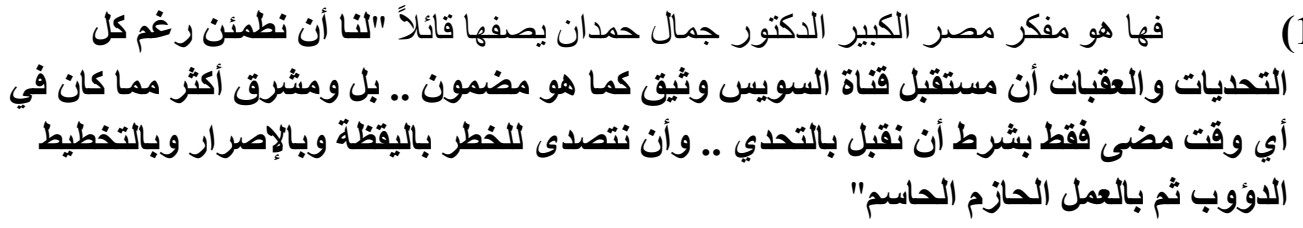

(13)

Egypt's great thinker Gamal Hemdan once said of it: "We can rest assured that, despite all challenges and impediments, the future of the Suez Canal will be secure and guaranteed. Its future is even brighter than before, provided we accept any challenge and address any danger with vigilance, determination, diligent planning and hard, persistent work"

El-Sisi borrows an extract from the Egyptian great thinker Gamal Hemdan in order to emphasize the idea that the future of the Suez Canal is bright and secure provided that we accept challenges and confront dangers with determination, planning and hard, persistent efforts. He resorts to intertextuality as a tool for persuasion.

\subsubsection{Religious expressions}

The speaker has used a religious lexical register in his speech. Following are some of the religious expressions employed by the Egyptian President in his speech:

$$
\text { استطعنا بفضل الله عز وجل ثم بجهد المصريين التغلب على تلك الظروف وتحقيق الحلم. }
$$

(14) Yet we were able with God's blessing and with the efforts of the

Egyptian people to triumph and realize our dream.

$$
\text { أشكر الله عز وجل أن وفقنا جميعاً لإنجاز هذا الحلم الكبير. }
$$

(15)

thanking God Almighty for helping us realize this ambitious dream

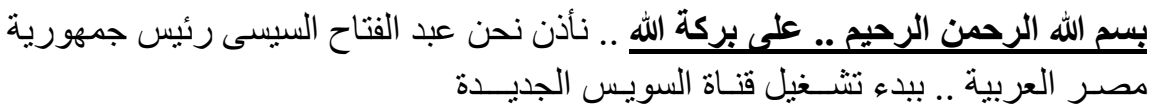

"In the name of God, the Most Gracious, the Most Merciful". "By the blessings of God, I, Abdel Fattah El Sisi, the President of the Arab Republic of Egypt, officially open the New Suez Canal",

El-Sisi is thanking God for helping the Egyptians to realize this ambitious dream. Furthermore, it is by the blessings of God that he announces the official opening of the New Suez Canal.

\subsubsection{Figures of speech}


Any critical linguistic study on political discourse always takes figures of speech; e.g. simile, metaphor, etc into account since these add flavor to the political speech. Figures of speech involve the employment of words out of their usual use or their literal meaning in order to add beauty and emotion to the text. The use of figures of speech reflects the speaker's ability to produce an emotive and effective speech that will affect the audience's thoughts and attitudes towards the points raised in the speech (Al-Hamad \& Al-Shunnaq, 2011).

Every language has its own figures of speech because every language has different linguistic and cultural properties. Because Arabic language is full of figurative expressions, Arab politicians rely heavily on the use of these figurative expressions to deliver a successful speech (Al-Hamad \& Al-Shunnaq, 2011). This study focuses on four figures of speech: simile, metaphor, personification and dysphemism.

\subsection{Simile}

A simile is a figure of speech that involves an implicit comparison between unlike things. A simile can be defined as "an explicit comparison between things that are essentially different yet have something in common" (Lucas , 1992, p. 223). It always contains the words 'like' and 'as'. A simile or metaphor has three parts: the topic, the image itself (the representative figure) and the point of similarity and comparison (the actual meaning of simile or metaphor in the passage). The following are some examples quoted from El-Sisi's speech:

$$
\text { فالقتاة الجديلة خطوة واحدة على طريق طويل }
$$

(17)

$$
\text { The new canal is one step on a long road }
$$

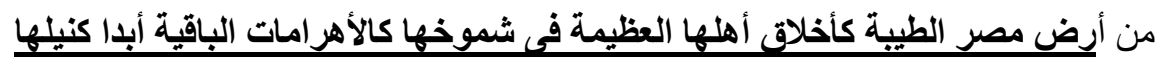

الخالد

(18)

from the land of Egypt which is as generous as its people, as glorious as the great pyramids, as everlasting as the eternal River Nile

$$
\text { كيف كانت قناة السويس محورا لانطلاق اشعاع مصر الثقافى و الحضارى للمنطقة و العالم }
$$

the Suez Canal was the springboard from which Egypt's cultural and civilizational influence radiated throughout the region and the world beyond,

In examples (17) and (19), El-Sisi uses similes to glorify the role of the new Suez Canal. It is being described as one step on a long road of achievements to be 
accomplished in the future and as having always been the springboard from which Egypt's cultural and civilizational influence radiated throughout the region and the whole world. In example (18), the similes are used to praise Egypt: the land of Egypt is described as being generous like the Egyptians, as glorious like the great pyramids and as everlasting like the eternal River Nile.

\subsection{Metaphor}

Linguists state that a metaphor involves a semantic mapping from one conceptual domain to another, often using anomalous or deviant language (Crystal, 1994). In employing metaphors, political actors use a word or phrase to establish a comparison between one idea and another. The employment of metaphors in political discourse is intentional and functional to draw the attention of the audience and to gain their sympathy and emotions towards what is being said. The following are some examples quoted from El-Sisi's speech:

قوى الارهاب و التطرف تحارب مصر و المصريين

(20) The powers of terrorism and extremism were at war with Egypt and the Egyptians.

$$
\text { نهاى للعالم شريانا اضافيا للرخاء وقناة تو اصل حضارى بين الثعوب }
$$

(21) We are providing the world an additional artery for prosperity and a channel for connecting civilizations

$$
\text { واقعا جديدا يجرى متدفقا فى مياه هذه القناة }
$$

(22) a new reality is now flowing through the water

It can be noted that El-Sisi has created new metaphors. These metaphors are innovative and highly emotive. In example (21), there is a reference to terrorism and extremism as powers which fight Egypt and the Egyptians. In examples (21) and (22), the use of metaphors enlivens the role played by the Suez Canal: it is an additional artery, a channel for connecting civilizations and a new reality.

\subsection{Personification}

Personification is a figure of speech in which the characteristics of humans are attributed to animals or inanimate objects. Personification is used in political discourse to give a lively image as well as an expressive and emotive meaning (AlHammad \& Al-Shunnaq, 2011). Following are examples quoted from the speech under investigation:

$$
\text { و ها هى مصر تقدم اليوم هليتهيا الى العالم }
$$

And today Egypt presents its gift to the world 
و سيذكر التاريخ لمصر و شعبها أنهما تصديا لأخطر فكر ارهابى منطرف لو تمكن من

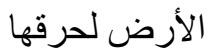

(24) History will judge that Egypt and its people confronted the most dangerous, extremist, terrorist thinking, which, had it prevailed, would have set the world ablaze.

$$
\text { قناة السويس جزءا من نبض مصر }
$$

(25) The Suez Canal has always been at the very heart of Egypt.

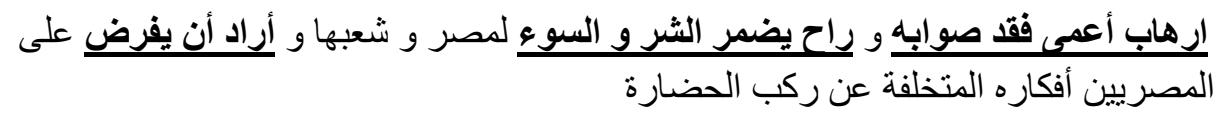

(26) blind, mindless terrorism, which harbors evil, means the people of Egypt harm and wants to impose regressive ideas on them.

$$
\text { ان التاريخ يروى للانسانية بأسر ها }
$$

(27) History will judge that

$$
\text { هذه القناة التى وضعت بصماتها على جغر افيا الوجود و خريطة البشرية }
$$

(28) the canal which has left its mark on the map of humanity

$$
\begin{aligned}
& \text { مصر التى استعادت ارادتها مع ثورتى الخامس و العشرين من يناير و الثلاثين من يونيو.. قد } \\
& \text { اختارت سبيلهاو أنارت دربهاو ان كانت لع تصل بعد الى كل ما تريد فانها عرفت كل ما تريدو و } \\
& \text { تمضى فى طريقها لتحقيقه }
\end{aligned}
$$

(29) Egypt, which has restored its will with the January 25 and June 30 revolutions, has chosen its path and illuminated its way forward. Although it has not yet accomplished all it has set out to do, it knows what it wants and is moving forward to realize it.

In examples (23), (25) and (29), the Egyptian President personifies Egypt as a human who presents her gift to the world, who has restored her will after two revolutions, who has chosen her path, who knows what she wants and is moving forward to achieve it. Again, in example (28), the speaker personifies the Suez Canal as a human who has left his mark on the world map. The purpose behind this personification is to highlight the role of Egypt and the role of the Suez Canal. In examples (24) and (27), he personifies history as a man who can judge that Egypt has confronted blind and 
mindless terrorism. In example (26), El-Sisi personifies terrorism as a man who is blind and mindless and who imposes his regressive ideas on the Egyptians.

\subsection{Dysphemism}

Dysphemism means saying something in a direct way which may negatively affect the other participant. Burridge and Allan (2001) define dysphemism as "an expression with connotations that are offensive about the denotatum or to the audience, or both, and it is substituted for a neutral or euphemistic expression for just that reason." In his speech, El-Sisi employs strong dysphemism expressions in order to arouse the emotiveness of his audience. We can consider the following examples:

وسيذكر التاريخ لمصر وشعبها أنهما تصديا لأخطر فكر إرهابى متطرف لو تمكن من الأرض لحرقها.

(30) History will judge that Egypt and its people confronted the most

dangerous, extremist, terrorist thinking, which, had it prevailed, would have set the world ablaze.

$$
\text { لقد قام الشعب المصري بإنجاز مشروع القناة الجديدة في ظروف صعبة على الصعيدين }
$$

(31) The Egyptian people completed the New Suez Canal under the most difficult circumstances economically and in terms of security. The powers of terrorism and extremism were at war with Egypt and the Egyptians.

$$
\begin{aligned}
& \text { ولقد كان رجال القوات المسلحة والثرطة المدنية فى طليعة الصفوف المصرية .. التى تسعى }
\end{aligned}
$$

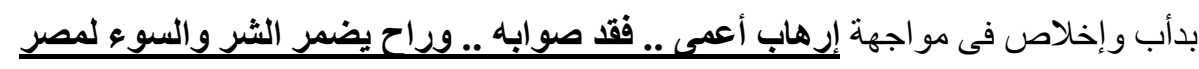

$$
\begin{aligned}
& \text { وشعبها .ـ وأراد أن يفرض على المصريين أفكاره المتخلفة عن ركب الحضارة فكانت إرادتهم } \\
& \text { وقدرتهم على هزيمته ودحره أقوى من حقده و عنفيه }
\end{aligned}
$$

(32) The men of the armed forces and police have been serving faithfully and diligently on Egypt's front line in a confrontation with blind, mindless terrorism, which harbors evil, means the people of Egypt harm and wants to impose regressive ideas on them. However, the will and determination of the Egyptian people to defeat and eradicate the terrorists has proved stronger than their violence and malice.

A quick glimpse at the above mentioned examples $(30-32)$, we can see how El-Sisi employs powerful and straightforward dysphemism expressions to amplify the meanings of these expressions and to arouse the emotions of his audience. His speech style is critical because he believes that the Egyptians have been suffering from blind 
terrorism and extremism which was at war with Egypt and the Egyptians and which wanted to impose regressive ideas on them.

\subsubsection{Repetition}

Al-Jubouri (1984) who examines the function of repetition in Arabic argumentative discourse observes that repetition may fall under one of three levels: the morphological level, the word level and the chunk level.

Regarding repetition at the morphological level, he claims that repetitive forms are formed either on the same morphological root or on the same morphological pattern which create two different types of morphological pattern: root repetition and pattern repetition.

Johnstone (1991) claims that verbal and nominal roots in Arabic language are ordered sets of three consonants $(J-\varepsilon-\omega)$ and each root has a general meaning that dominate the meaning of all forms in which it is realized. In general, morphological repetition of roots is created by the multiple use of the same root within a single clause. The following is an example:

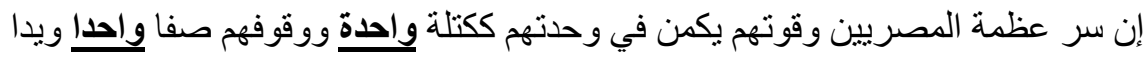

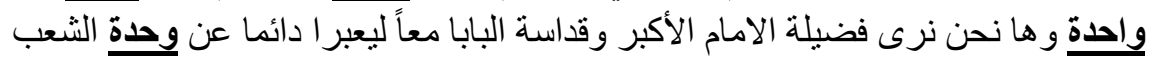

$$
\begin{aligned}
& \text { المصري }
\end{aligned}
$$

(33) The secret to the greatness of the Egyptian people and to their strength lies in the fact that they are united as one entity, standing together hand in hand. And so we see the Grand Imam and the Pope standing together to express the everlasting unity of the Egyptian people.

In this extract, root repetition is created by the re-occurrence of the tri-lateral root (وحد). In extract (33) the word واحد is repeated four times in emphasize the unity of the Egyptians.

The following is an example of pattern repetition:

$$
\begin{aligned}
& \text { من أرض مصر الطيبة كأخلاق أهلها .. العظيمة في شموخها كالأهر امات .. العبقرية في }
\end{aligned}
$$

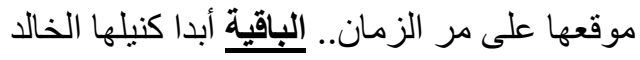

(34) From the precious land of Sinai, the meeting point of East and West, from the land of Egypt which is as generous as its people, as glorious as the great pyramids, as everlasting as the eternal River Nile, and as incomparable as it is timeless

Morphological parallelism occurs through the use of the overt feminine indicator ( $\ddot{0})$ in four adjectives. 
Word level repetition is classified by Al-Jubouri as the use of what he calls "word strings". He observes that word repetition in Arabic language is not merely an ornamental device, but it has a crucial rhetorical function. According to Al-Khafaji (2005), repetition "can have didactic, playful, emotional, artistic, textual and rhetorical functions". The following extracts from El-Sisi's speech illustrate this point.

In the following extract, the phrase تحيا مصر has been repeated three times.

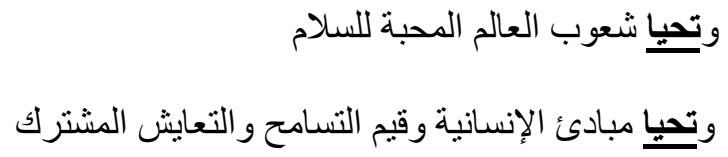

(35) Long Live the peace-loving nations around the globe

Long Live the principles of humanity and the values of tolerance and co-existence

The message the speaker intends to convey here is spreading the principles of humanity and the values of tolerance and co-existence.

Word strings in this political speech are ideologically employed to reinforce and achieve certain political strategies.

Chunk repetition is defined by Al-Jobouri as parallelism construction. He divides parallelism which involves resemblance in grammatical structures and word order into two types: complete parallelism and incomplete parallelism. Al-Jobouri's classification can be illustrated in the following two examples:

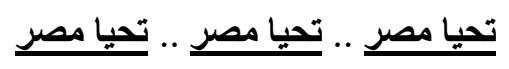

(36) Long Live Egypt ..Long Live Egypt..Long Live Egypt

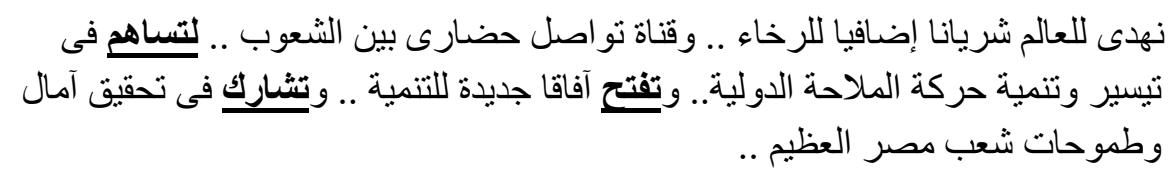

(37) We are providing the world an additional artery for prosperity and a channel for connecting civilizations. It will facilitate and enhance the movement of international maritime traffic, broaden the horizons of growth and enable the realization of the hopes and aspirations of the great people of Egypt

Complete parallelism which refers to the total correspondence between parallel structures is clear in the first example. The three parallel structures share the same word order and grammatical structure which includes verb and noun. Partial 
correspondence between parallel structures in the second example is what Al-Jobouri calls incomplete parallelism. It is introduced by the present tense. The other constituents in two clauses vary in their syntactic constructions. The first and third ones are followed by prepositional phrases and the second one is followed by an object.

El-Sisi's discourse is full of praise for Egypt and the Egyptians. He is glorifying the Egyptians. Repetition is used to emphasize his praise. The repetition of some emotive words was observed. The following table illustrates the most frequently repetitive words in El-Sisi's speech.

Table 2. The frequency of repetitive words in EI-Sisi's speech

\begin{tabular}{|c|c|c|}
\hline The word in Arabic & $\begin{array}{c}\text { The translation in } \\
\text { English }\end{array}$ & Frequency \\
\hline مصر & Egypt & 32 times \\
\hline المصري / المصريين & Egyptian(s) & 14 times \\
\hline قناة & Canal & 17 times \\
\hline انجاز & Achievement & 14 times \\
\hline ارهاب & Terrorism & 4 times \\
\hline شكر & Thanking & 4 times \\
\hline
\end{tabular}

El-Sisi repeats the word مصر (Egypt) 32 times, المصري / المصريين (Egyptian(s)) 14 times, قناة (Canal) 17 times and انجاز (achievement) 14 times. We can note that this repetition is functional and communicative. He wishes to send a message of praise emphasizing the glorious history of Egypt and the capabilities of the Egyptians.

He also repeats the word ارهاب (terrorism) 4 times. This repetition is functional and ideological because he shows that Egypt has been suffering from black terrorism during the various stages of implementing this project.

El-Sisi also repeats the word شكر (thanking) because he wants to express gratitude for all the parties that have taken part in this great project: Egyptians, Armed Forces and fallen heroes who sacrificed their lives for the sake of the country.

\subsubsection{Synonymy}

Synonymy can be described as words which signify the same meanings. Synonymy does not mean identical meaning between two words but the two words can be used in different contexts giving a similar meaning (Abed-Raof, 2001). Koch (1983, p. 5152) examines synonymy in terms of what she calls "lexical couplets" where a lexical couplet is a structure of the form $\mathrm{AxB}$ which meets the following criteria:

1. $\mathrm{x}$ is a coordinating conjunction, usually additive (and), but occasionally disjunctive (or)

2. A and B are synonyms or near-synonyms 
3. The structure AxB has a single referent; it is used to refer to a single object, action, or state, rather than to temporally or logically discrete objects, actions, or states

$$
\text { و ولكن أيضا لمنح الأمل لأجيال قادمة .. ستعى وتتعلم من تجاربكم وتاريخكم معانى الفداء و التضحية }
$$

(38) but will also inspire future generations, who will learn from your experience the meaning of redemption, sacrifice and altruism.

$$
\text { و ولقد كان رجال القوات المسلحة والثرطة المدنية فى طليعة الصفوف المصرية . . التى تسعى بدأب }
$$

(39) The men of the armed forces and police have been serving faithfully and diligently on Egypt's front line in a confrontation with blind, mindless terrorism

$$
\text { مو اجهة إر هاب أعمى .. فقد صوابه .. وراح يضمر الثر والسوع لمصر وشعبها .. }
$$

(40) in a confrontation with blind, mindless terrorism, which harbors evil, means the people of Egypt harm

$$
\text { فكانت ارادتهم و قدرته على هزيمته و دحره أقوى من حقده و عنفه }
$$

(41) the will and determination of the Egyptian people to defeat and eradicate the terrorists has proved stronger than their violence and malice.

Synonymy is used to reinforce meaning. In extract (38), there is an emphasis on the fact that future generations will learn from the history and experience of the Egyptians. In extracts (39) and (40), there is an emphasis on the glorious role of the Armed forces and the will and determination of the Egyptians. Furthermore, the use of synonyms in extracts 40 and 41 reinforces the attributes of the enemies: evil, harm and violence.

\subsubsection{Collocation}

Collocation is the use of "a word that is in some way associated with another word in the preceding text because it is a direct repetition of it, or is in some sense synonymous with it, or tends to occur in the same lexical environment" (Halliday and Hasan, 1976). This means that collocation refers to the habitual co-occurrence of individual lexical items. The main lexical item in collocation is described as a "nodal item" and what collocates with this item is described as "collocational range" (AdelRaof, 2001). Following are examples of collocation in the speech under investigation:

$$
\text { أصحاب الجلالة و الفخامة و السمو }
$$


(42) Your Majesties, Excellencies and Highnesses

من أر ادو ا أن يشاركو ا شعبها العظيم فرحته بإنجازه التاريخي ..الذى أثبت من خلاله قدرته على الته

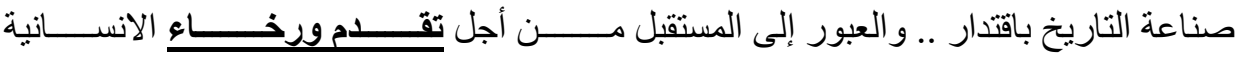

بأكملهـا

(43) who want to join its great people in their joy at this momentous accomplishment, through which they proved their ability to make history and forge a prosperous future for humanity as a whole.

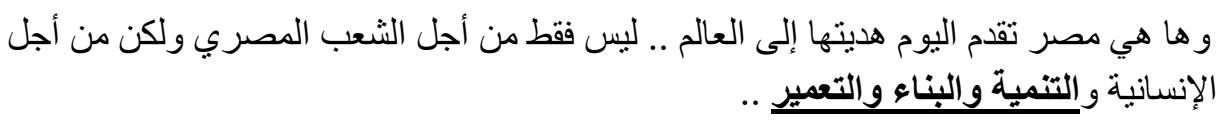

(44) And today Egypt presents its gift to the world for the sake of humanity, reconstruction and development.

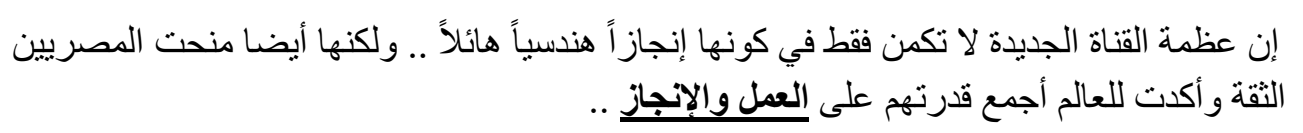

(45) The splendor of this new canal not only represents a formidable feat of engineering, but has also given the Egyptian people confidence and demonstrated to the entire world what they are capable of accomplishing.

$$
\begin{aligned}
& \text { كما أتقدم بوافر الثكر و التقدير للهيئة الهندية للقو ات المسلحة ولهيئة قناة السويس وتحالف } \\
& \text { شركات التكريك وشركات المقاو لات .. }
\end{aligned}
$$

(46) I would also like to offer my gratitude and appreciation to the Engineering Authority of the armed forces, the Suez Canal Authority and the consortium of dredging and construction companies

$$
\text { و اسمحو الى أن أوجه رسالة إعزاز وتقدير لشعب بلادى . }
$$

(47) Allow me to send a message of appreciation to the people of my country

$$
\text { و الإيثار . . ولنا لمنح الأمل لأجيال قادمة .. ستعى وتتعلم من تجاربكم وتاريخكم معانى الفداءو والتضحية }
$$

(48) but will also inspire future generations, who will learn from your experience the meaning of redemption, sacrifice and altruism.

$$
\begin{aligned}
& \text { إن إنطلاق حركة الملاحة البحرية فى قناة السويس الجديدة .. و إنجاز ها بهذه المعدلات غير }
\end{aligned}
$$

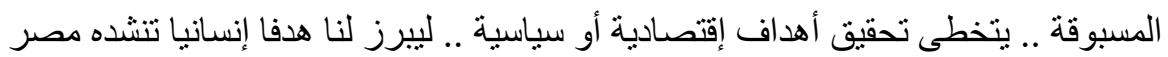


(49) The opening of the New Suez Canal to maritime traffic on such an unprecedented accelerated timetable has an impact that goes beyond political and economic goals. It underscores the humanitarian dimension to which the Egypt of the future aspires; one where dignity, justice and stability are realized.

The above analysis has shown how repetition, synonymy and collocation, tools for lexical cohesion, have been employed to reinforce and support El-Sisi's ideology and political strategies. One of these strategies is to express self-confidence and encourage hope through the persuasive act of repeating positive phrases which creates a sense of hope and patriotism among the audience. Another is the decoration of confrontation strategy through which he refers to the threat of terrorism underscoring the importance of enemy in order to defeat the enemy. To deliver this strategy, he has resorted to the repetition of key concepts and terms that have both emotional and persuasive power.

\section{Conclusion}

The present study has answered its two questions. The first question is: "What are the key intended ideologies enhanced and involved in El-Sisi's speech?" The results of the first part of our analysis have shown that the key ideological components of the speech can be summarized into the following core concepts:

a) Thanking all those who contributed to the completion of this project: Egypt's fallen heroes who sacrificed their souls in order for their homeland to establish stability, the Egyptians who proved that Egypt will never cease to raise new generations of loyal citizens and authorities like the Engineering Authority and the Suez Canal authority, etc.

b) Declaring strength and confrontation: the New Suez Canal project was completed under the most difficult circumstances whether economically or in terms of security. Though Egypt and the Egyptians were at war with the powers of terrorism and extremism, they were able with God's blessings and persistent efforts to realize their dream.

c) Expressing self-confidence: this project has given the Egyptian people confidence and demonstrated to the whole world they are capable of accomplishing. It is the first in a number of national projects. Having restored its will with the January 25 and June 30 revolutions, Egypt knows now what it wants and is moving forward to realize it.

The overall underlying theme of the speech is emphasizing that the future of the New Suez Canal is bright and secure provided that we confront current challenges and dangers with determination, planning and hard work. 
This paper analyzed the ideological component of El-Sisi's political speech. The analysis is embedded in Fairclough's notions of ideology residing in text. The researcher has attempted to use another concept of Fairclough, namely that "meanings are produced through interpretations". In this process the framework of El-Sisi's ideological standpoint as present in the speech has been identified. The researcher's analysis and interpretation of the ideological aspect of the speech was an attempt to link the discourse with the social processes and to decipher the covert ideology of the text under investigation. This paper attempted to deconstruct covert ideology which is hidden in the text.

The second question is: "What are the distinctive linguistic features and strategies adopted by the speaker to convince his audience to believe in his ideas?" The findings of the study have shown that the speaker resorts to intertextuality and the use of religious expressions and that different linguistic techniques are used by the president to deliver his messages and get his audience believe in them. Among these are figures of speech, repetition, synonymy and collocation. The results of the keyword analysis have shown that the most prominent words employed by El-Sisis are Egypt, Egyptians, Canal, achievement, thanking and terrorism.

One can conclude from the above analysis that the language in El-Sisi's speech shapes and is shaped by the social, cultural and political factors surrounding him. In this paper, I have argued that intertextuality of text, combined with figures of speech, repetition, synonymy and collocation have been employed extensively in El-Sis's speech not only to elevate the language style, but also to serve various ideological purposes. It has been used to reinforce the various strategies and to influence and persuade his audience. The use of different discourse registers in El-Sisi's speech, combined with extensive use of repetition, shows clearly that language as a means of communication can be carefully employed not only to demonstrate the stylistic command of the speaker but also to convey his views, manifested in his attempt to have a lasting impact on the audience and recipients of his speech.

While a positive register is adopted when referring to the Egyptians, a repetitive negative register is used in addressing their opponents. By attacking the enemy's action and labeling it as blind terrorism, the speaker seeks to persuade the audience through the paradigm of 'them' against 'us'. This paradigm has been used by different political leaders during times of conflict to rally their nations and supporters behind them (van Dijk 1991).

CDA explores the relationship between ideology and language. It provides useful approaches for analyzing public speeches. In this study, understanding the social and historical factors that led to the text production paved the way for a better understanding of the text. The linguistic practice and socio-cultural practice interrelatedness as proposed by Fairclough have been shown by the results of the analysis. 


\section{Recommendations}

Having studied the speech delivered by the Egyptian president, the researcher recommends the following for further research:

1) Reinvestigating other kinds of texts and speeches in the Arabic language, applying principal tenets of Critical Discourse Analysis and Political Discourse Analysis.

2) Reinvestigating other speeches of President El-Sisi, coaching with the Critical Discourse Analysis themes.

3) Conducting a study indicating whether El-Sisi follows the same strategies in his other speeches.

4) Applying other political discourse strategies such as euphemism and rhetoric on El-Sisi's speeches 


\section{References}

Abed-Raof, H. (2001). Arabic Stylistics: A Course Book. Wiesbaden:

Harrassowitz Verlag.

Abu Hatab, W. (2013). Arab Spring Presidential Speeches and New Social Identities: A Critical Discourse Analysis Study. The European Conference on Arts \& Humanities. Official Conference Proceedings 2013. Retrieved on 14/ 8/ 2015, available at http://iafor.org/archives/offprints/ecah2013-offprints/ECAH2013_0459.pdf

Al-Hamad, M. Q. \& Al-Shunnaq, M. A. (2011). Emotive expressions in President Bashar Al-Assad's Political Speeches. Onomazein, 23(1), 149-170. Retrieved on $14 / 8 / 2015$, available at

https://repositorio.uc.cl/bitstream/handle/11534/8043/000573816.pdf?sequenc e=1\&isAllowed $=\mathrm{y}$

Al-Harahsheh, A. M. (2013). The Translatability of Figures of Speech in Khalid Mashaal's Political Speeches: A Critical Discourse Analysis. International Journal of English Linguistics, 3(3), 100-114. Retrieved on 14/ 8/ 2015, available at http://www.ccsenet.org/journal/index.php/ijel/article/viewFile/25351/16690 Al-Haq, F. A. \& Al-Sleibi, N. M. (2015). A Critical Discourse Analysis of Three Speeches of King Abdullah II. US-China Foreign Language, 13(5), 317-332. Retrieved on 28/ 10/2015, available at http://www.davidpublisher.org/Public/uploads/Contribute/55823dfe54f29.pdf Al-Jubouri, A. (1984). The Role of Repetition in Arabic Argumentative Discourse. In Swales, J. and Mustafa, H. (eds.). English for Specific Purposes in the Arab World (pp. 99-117).

Al-Khafaji, R. (2005). Variation and Recurrence in the Lexical Chains of Arabic and English texts. Poznan Studies in Contemporary Linguistics, 40, 5-25. 
Retrieved on 13/3/2016, available at http://www.gespin.amu.edu.pl/psicl/files/40/01Al-Khafaji.pdf

Al Majali, W. (2015). Discourse Analysis of the Political Speeches of the Outsted Arab Presidents during the Arab Spring Revolution using Halliday and Hasan's Framework of Cohesion. Journal of Literature, Languages and Linguistics, 10, 35-48. Retrieved on 14/ 8/ 2015, available at file:///C:/Users/Hello/Downloads/22650-24911-1-PB.pdf

Bayram, F. (2010). Ideology and Political Discourse: A Critical Discourse Analysis of Erdogan's Political Speech. ARECLS, 7, 23-40. Retrieved on 13/ 8/ 2015, available at http://research.ncl.ac.uk/ARECLS/volume7/bayram_vol7.pdf

Brown, G. and Yule, G. (1983). Discourse Analysis. Cambridge: Cambridge University press.

Burridge, K. \& Allan, K. (2001). Euphemism \& dysphemism: Language used as a shield and weapon. Bridgewater, N.J.: Replica Books.

Chilton, P. A. (2004). Analyzing political discourse: theory and practice. AbingdonNew York: Routledge.

Chilton, P. A. and C. Schaffner. (1997). Discourse and Politics in T. van Dijk (ed.), Discourse as Social Interaction, London, Sage: 206 - 30.

Crystal, D. (1994). An encyclopedic dictionary of language and languages. Oxford: Blackwell

Fairclough, N. (1989). Language and Power. London: Longman.

Fairclough, N. (1992). Language and Social Change. London: Polity Press.

Fairclough, N. (1995). Critical Discourse Analysis: the critical study of Language. New York: Longman.

Fairclough, N. \& Wodak, R. (1997). Critical Discourse Analysis. In van Dijk, T. A. (Ed.), Discourse as social interaction: A multidisciplinary introduction, 
2, 258-84. London: Sage Publications Ltd.

Fairclough, N. (1999). Critical Discourse Analysis: The Critical Study of Language. London: Longman.

Gang, W. \& Qiao, L. (2014). On the Theoretical Framework of the Study of

Discourse Cohesion and Coherence. Studies in Literature and Language, 8 (2), 32-37. Retrieved on 13/ 8/ 2015, available at file:///C:/Users/Hello/Downloads/4512-9726-1-PB.pdf

Halliday, M.A.K. and Hassan, R. (1976). Cohesion in English. London: Longman. Horvath, J. (2009). Critical Discourse Analysis of Obama's Political Discourse. In M. Ferencik \& J. Hovath (Eds.). International conference proceedings of language, literature and culture in a changing transatlantic world, 45- 56. Presov: University of Presov.

Janks, H. (1997). Critical Discourse Analysis as a Research Tool. Discourse: Studies in the Cultural Politics of Education, 18(3), 329-342.

Johnstone, B. (1991). Repetition in Arabic Discourse: Paradigms, Syntagms, and the Ecology of Language. Amsterdam: John Benjamins.

Kazemian, B. \& Hashemi, S. (2014). Critical Discourse Analysis of Barack Obama's 2012 Speeches: Views from Systemic Functional Linguistics and Rhetoric. Theory and Practice in Language Studies, 4 (6), 1178-1187. Retrieved on $13 / 8 / 2015$, available at http://ojs.academypublisher.com/index.php/tpls/article/view/tpls04061178$1187 / 9405$

Koch. B. J. (1983). Arabic Lexical Couplets and the Evolution of Synonymy. General Linguistics, 23(1), 51-61.

http://repository.cmu.edu/cgi/viewcontent.cgi?article=1019\&context=english Lahlali, M. (2012). Repetition and Ideology in Nasrallah's Political Speech. Arab Media \& Society, 15, 1-13. Retrieved on 14/ 8/ 2015, 
available at http://www.arabmediasociety.com/?article=790

Lucas, S. (1992). The Art of Public Speaking. New York: McGraw-Hill Inc.

Matic, D. (2012). Ideological Discourse Structures in Political Speeches.

Komunikacija i kultura online, III (3), 54-78. Retrieved on 13/ 8/ 2015, available at

http://www.komunikacijaikultura.org/KK3/KK3Matic.pdf

Van Dijk, T. A. (1977). Coherence. Text and Context: Exploration in the Semantics and Pragmatics of Discourse. London: Longman.

Van Dijk, T. A. (1993). Principles of critical discourse analysis. Discourse and Society, 4(2), 249-83. Retrieved on 28/10/2015, available at http://discourses.org/OldArticles/Principles\%20of\%20critical\%20discourse \%20analysis.pdf

Van Dijk, T. A. (1995). Aims of Critical Discourse Analysis. Japanese Discourse, 1, 17- 27. Retrieved on $28 / 10 / 2015$, available at http://discourses.org/OldArticles/Aims\%20of\%20Critical\%20Discourse\%2 $\underline{\text { OAnalysis.pdf }}$

Van Dijk, T. A. (1997). What is Political Discourse Analysis? Belgian Journal of Linguistics, 11, 11-52. Retrieved on 13/ 8/ 2015, available at http://discourses.org/OldArticles/What\%20is\%20Political\%20Discourse\%2 OAnalysis.pdf

Van Dijk, T. A. (1998). Ideology: A Multidisciplinary Approach. London: Sage Publications.

Websites:

http://egyptianstreets.com/2015/08/06/egypts-new-suez-canal-through-the-eyes-of-

foreign-media/

http://www.bbc.com/news/world-africa-13313371

http://english.alarabiya.net/en/business/economy/2014/10/24/Analysts-Sisi-reformskey-to-Egypt-s-economic-upswing.html 


\section{APPENDIX A}

\section{Speech by the President of the Arab Republic of Egypt, Abdel Fattah El Sisi, at the Inauguration Ceremony of the New Suez Canal, Thursday, August 6, 2015}

\section{Available at: http://www.alarabyanews.com/18012}

$$
\begin{aligned}
& \text { أصحاب الجلالة و الفخامة و السمو.. } \\
& \text {.. السيدات و السادة .. ضيوف ولفامة ولسر الأعزاء }
\end{aligned}
$$

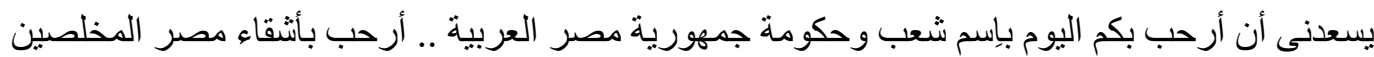

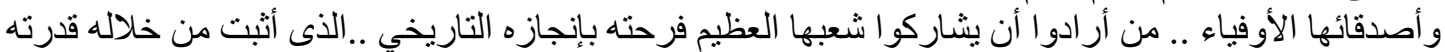

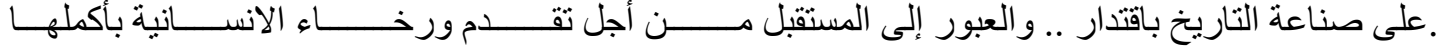

اسمحو الي أن أتحدث إليكم كمو اطن مصري يفخر بعظمة بلاده وبحضارتها العريقة التي تُدرس في العديد من العن العنا

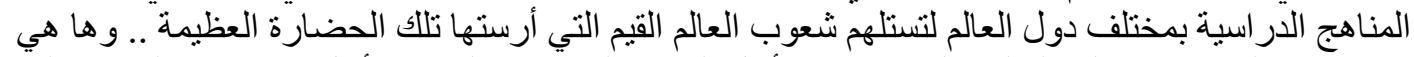

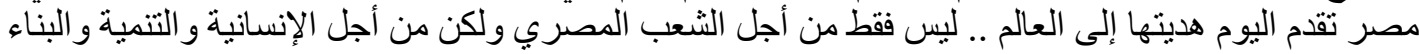

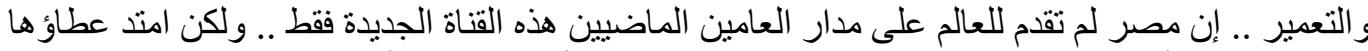

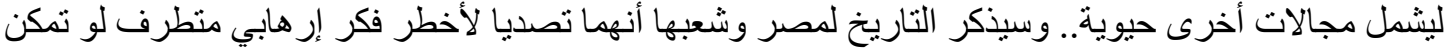

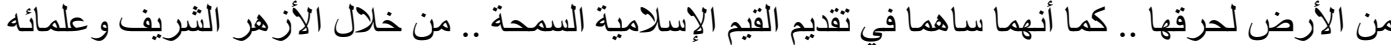
الأجلاء .. الذين يساهمون بفاعلية في تجديد الخطاب الديني وتصويبها

لقد قام الثعب المصري بإنجاز مشروع القناة الجديدة في ظروف صعبة على الإنى الصعيدين الاقتصادي و الأمني،

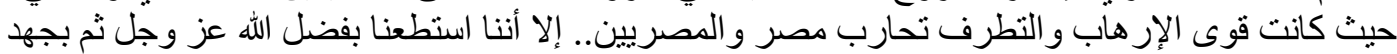
. المصريين التغلب على تللك الظروف وتحقيق الحلم

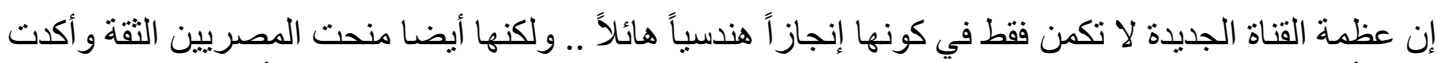

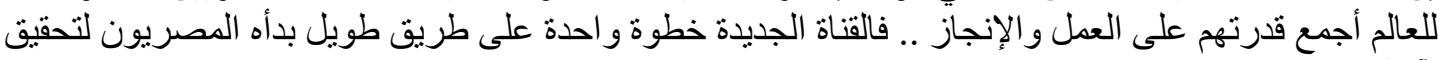

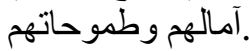

إن سر عظمة المصريين وقوتهم يكمن في وحدتهم ككتلة واحدة ووقوفهم صفا واحدا ويدا واحدة .. و ها نحن نرى إحى ـ فضيلة الامام الأكبر وقداسة البابا معاً ليعبر ا دائما عن وحدة الثعب المصري

ولن يفوتني هذا المقام أن أقدم الثكر لأرواح شهداء مصر الذين جادو ا بأنفسه ودمائهر من أجل هذا الوطن

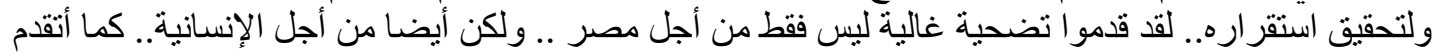

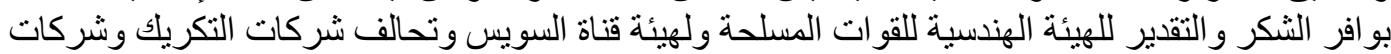
المقاو لات .. الذين ساهموا جميعاً في إنجاز هذا المشروع العظيم في نوقيته المحدد.

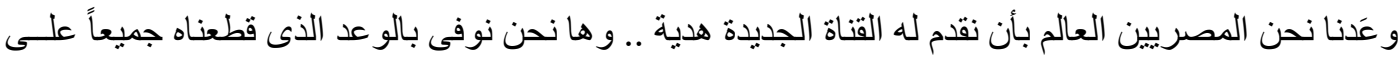

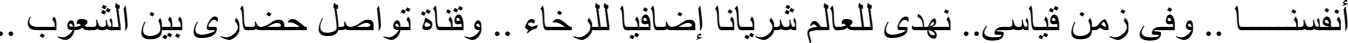

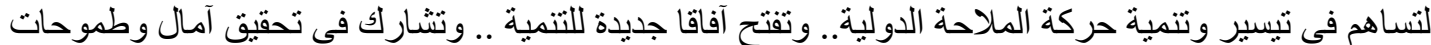
.شعب مصر العظيم .. الذى أنجز هذا المشروع بعقول أبنائه .. وقوة سو اعدهم . . ومدخر ات أمو الهم

من سيناء الغالية .. ملتقى الشرق و الغرب .. من أرض مصر الطيبة كأخلاق أهلها .. العظيمة في شموخها

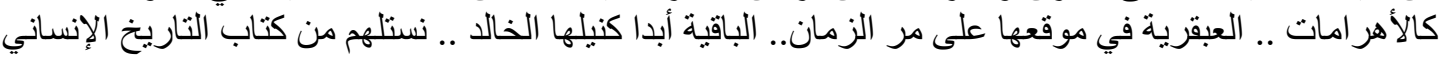




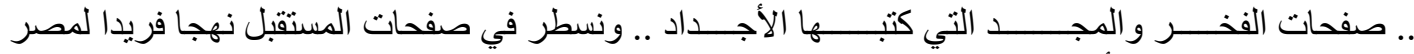
الجديدة يلبى طموحات أبنائها .. ويتسق مع كفاحهم ونضالهم المتند بامتداد البشرية.

لطالما كانت قناة السويس جز عاً من نبض مصر فشغلت مفكريها و أدباءها.. فها هو مفكر مصر الكبير الدكتور

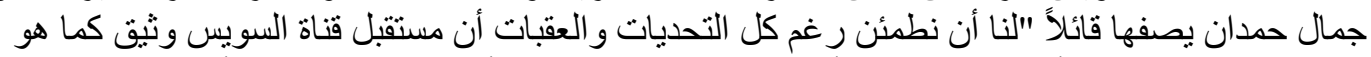

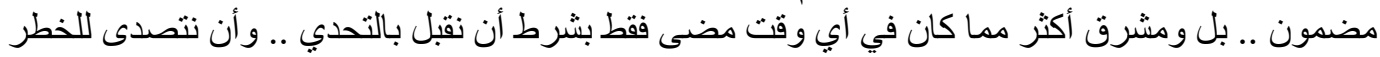

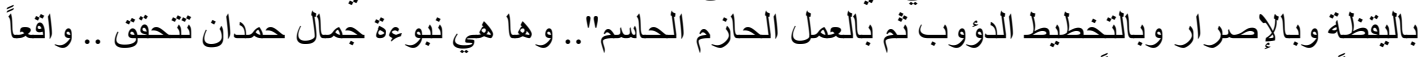
جديداً يجري الآن متدققاً في مياه هذه القناة.

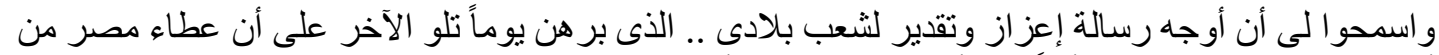

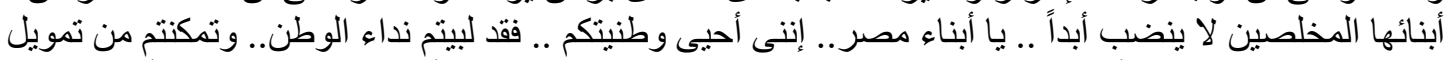

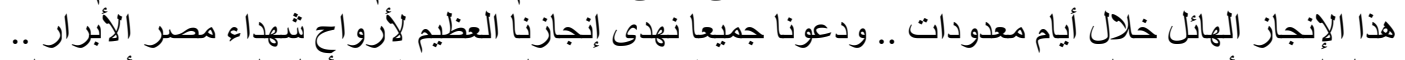

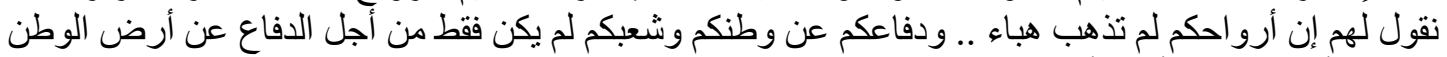

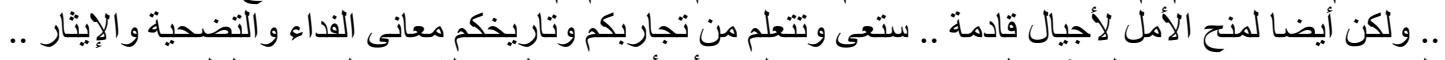

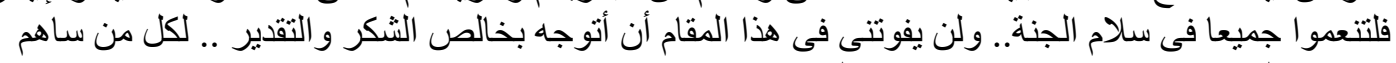

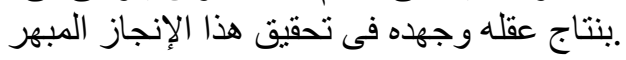

$$
\text { . أصحاب الجلالة و الفخامة و السمو . السيدات و السادة .. ضيوف مصر الأعزاء }
$$

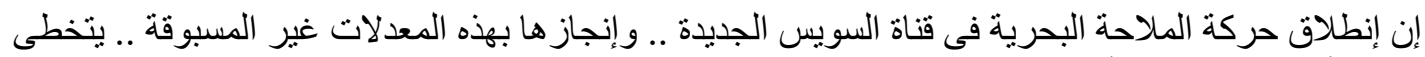

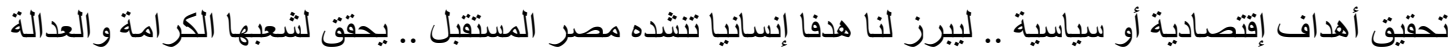

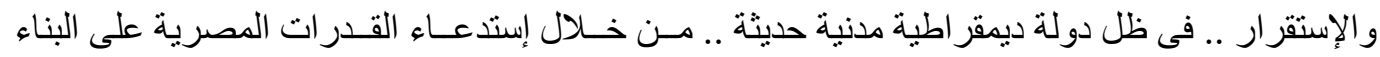

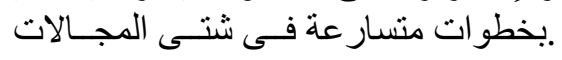

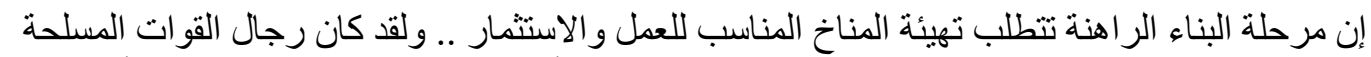

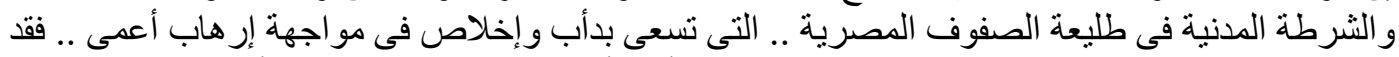

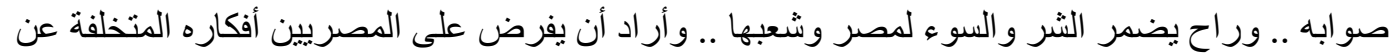

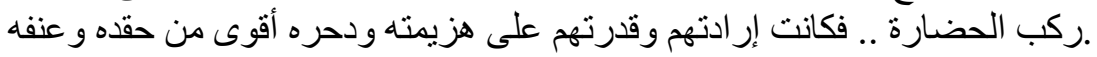

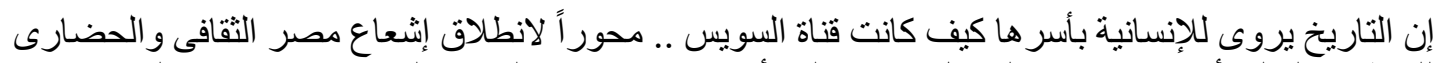

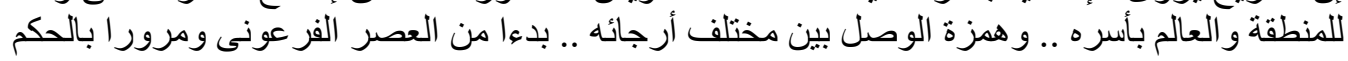

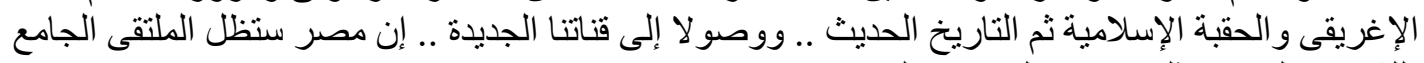
للشرق والغرب منلما كانت على مدار التاريخ.

$$
\text { .. . أصحاب الجلالة و الفخامة و السمو }
$$

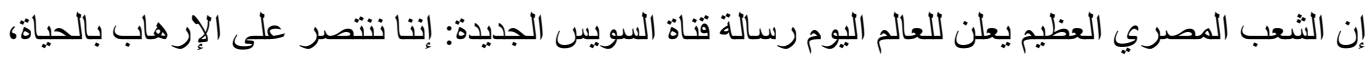

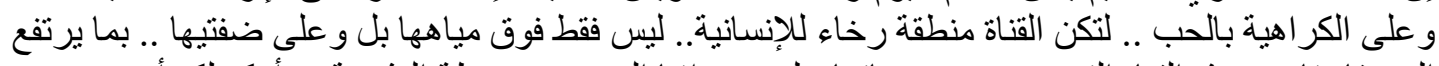

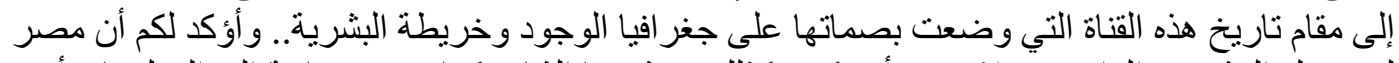

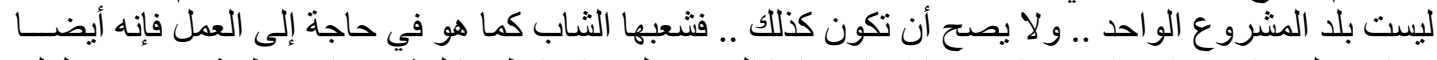

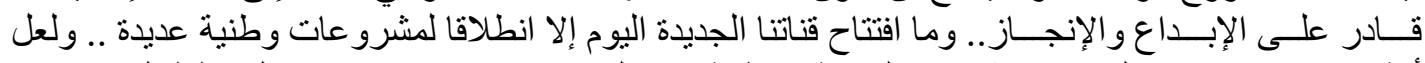

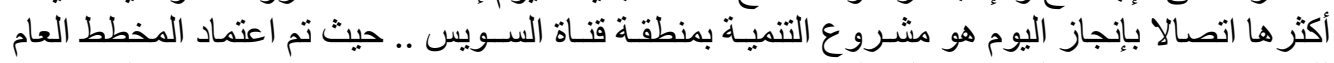

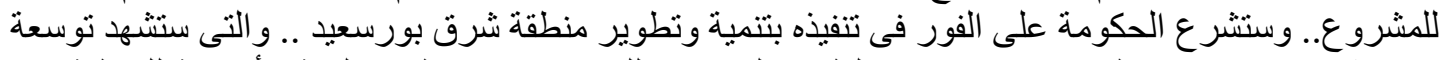

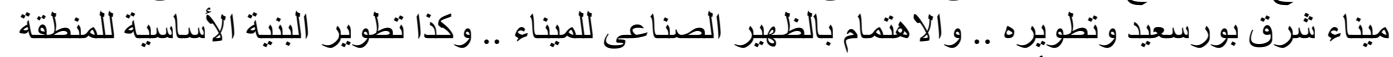
وربطها مع المشرو عات الأخرى الجارى تنفيذها .. وسيلى ذللك البدء مباثرة فئى تلنمية مناطق الإسماعيلية

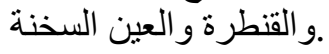


إن تنمية منطقة القناة تستهدف إنشاء منطقة إقتصادية عالمية .. تشمل عددا من الموانى أنو والمدن الجديدة و المر اكز

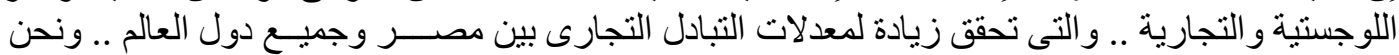

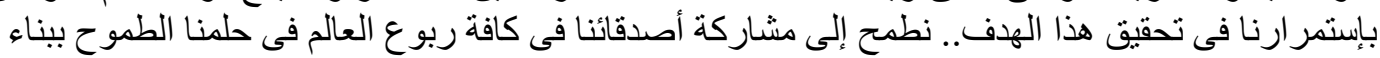

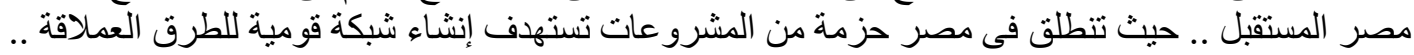

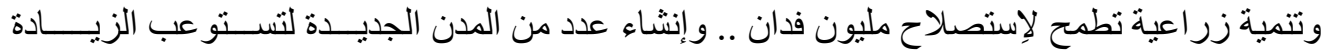

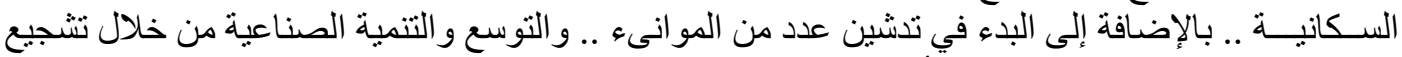

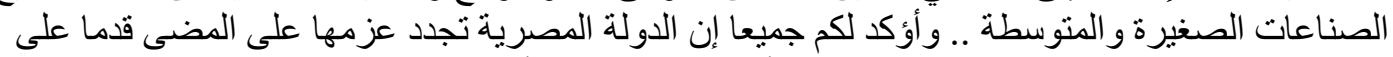

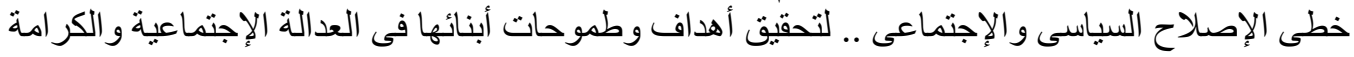
. الإنسانيـــة الإحتة

السيدات و السادة

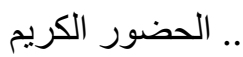

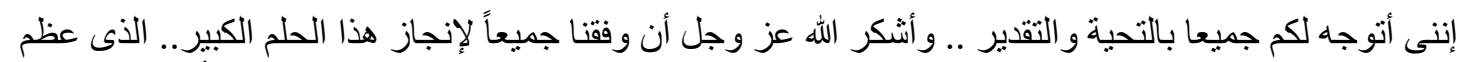

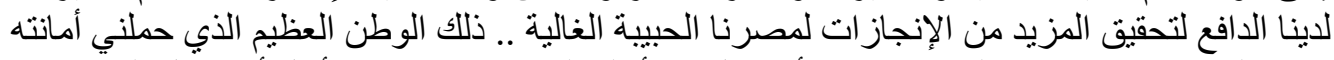

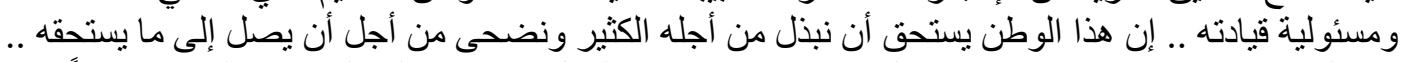

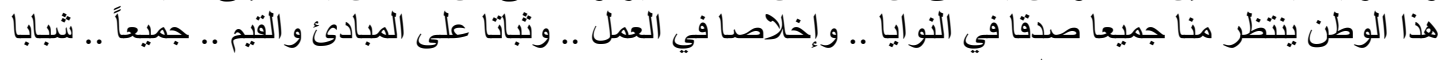
وشيوخا .. رجالا ونساء .. مسلمين ومسيحينين فئين.

إن مصر التي استعادت إر ادتها مع ثورتي الخامس و العشرين من يناير و الثناثثن من يونيو . .. قد اختارت سبيلها

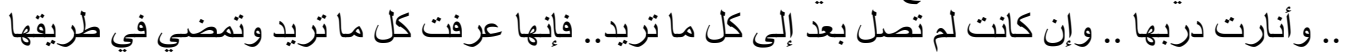

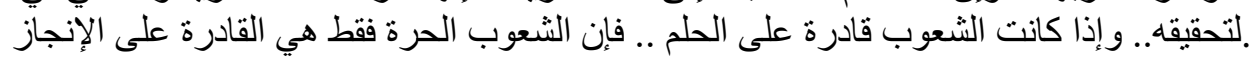

بسم الله الرحمن الرحيم .. على بركة الله .. نأذن نحن عبد الفتاح السيسى رئيس جمهورية مصـر العربية .. ببدء

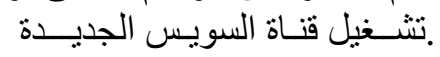

تحيا مصر .. تحيا مصر .. تحيا مصر

وتحيا شبادي الإبعانية العالم المحبة للسلام

وتحيا مبادئ الإنسانية وقيم التسامح و التعايش المشترك

و السلام عليكم ورحمة الله وبركاته، 


\section{APPENDIX B \\ English Translation of the Speech by the President of the Arab Republic of Egypt, Abdel Fattah El Sisi, at the Inauguration Ceremony of the New Suez Canal, Thursday, August 6, 2015}

\section{Available at: http://thecairopost.youm7.com/news/163086/news/full- text-of-sisis-speech-at-new-suez-canal-inauguration-ceremony}

Your Majesties, Excellencies and Highnesses..

Ladies and Gentlemen..

Dear Guests of Egypt.

It is my pleasure to welcome you today in the name of the people and government of the Arab Republic of Egypt. I welcome Egypt's loyal friends, who want to join its great people in their joy at this momentous accomplishment, through which they proved their ability to make history and forge a prosperous future for humanity as a whole.

Allow me to talk to you as an Egyptian citizen who takes pride in the magnificence of his country and ancient civilization, which is taught around the world so that the peoples of the world take inspiration from the values it espoused. And today Egypt presents its gift to the world for the sake of humanity, reconstruction and development. Over the last two years, Egypt's contributions to the world have extended beyond this new canal, to encompass other vital areas. History will judge that Egypt and its people confronted the most dangerous, extremist, terrorist thinking, which, had it prevailed, would have set the world ablaze. Egypt and its people also contributed by promoting the tolerant values of Islam through Al Azhar and its honorable scholars, who actively contributed in renewing the religious discourse and rectifying it.

The Egyptian people completed the New Suez Canal under the most difficult circumstances economically and in terms of security. The powers of terrorism and extremism were at war with Egypt and the Egyptians. Yet we were able with God's blessing and with the efforts of the Egyptian people to triumph and realize our dream.

The splendor of this new canal not only represents a formidable feat of engineering, but has also given the Egyptian people confidence and demonstrated to the entire world what they are capable of accomplishing. The new canal is one step on a long road the Egyptian people have embarked on to realize their aspirations and ambitions.

The secret to the greatness of the Egyptian people and to their strength lies in the fact that they are united as one entity, standing together hand in hand. And so we see the Grand Imam and the Pope standing together to express the everlasting unity of the Egyptian people. 
I owe a debt of gratitude to Egypt's fallen heroes who have made the ultimate sacrifice for their homeland in order to establish stability. Their sacrifice is not only for Egypt, but for all humanity. I would also like to offer my gratitude and appreciation to the Engineering Authority of the armed forces, the Suez Canal Authority and the consortium of dredging and construction companies, which all contributed to the completion of this project by the deadline that was set.

We, Egyptians, promised this new canal as a gift to the world; and today we are fulfilling this promise in record time. We are providing the world an additional artery for prosperity and a channel for connecting civilizations. It will facilitate and enhance the movement of international maritime traffic, broaden the horizons of growth and enable the realization of the hopes and aspirations of the great people of Egypt, who prevailed in this endeavor with their mental strength, physical effort and personal savings.

From the precious land of Sinai, the meeting point of East and West, from the land of Egypt which is as generous as its people, as glorious as the great pyramids, as everlasting as the eternal River Nile, and as incomparable as it is timeless, we are inspired by the pages of history inscribed with pride and glory by our forefathers to write the future chapter of a new Egypt, characterized by a unique approach that will fulfil the aspirations of its people in keeping with their struggle and strife, which is as old as humanity itself.

The Suez Canal has always been at the very heart of Egypt. As such it exercised the minds of its thinkers and writers. Egypt's great thinker Gamal Hemdan once said of it: "We can rest assured that, despite all challenges and impediments, the future of the Suez Canal will be secure and guaranteed. Its future is even brighter than before, provided we accept any challenge and address any danger with vigilance, determination, diligent planning and hard, persistent work". And now we see Gamal Hemdan's prophecy coming true, ten years after he made it, as a new reality is now flowing through the water of this canal

Allow me to send a message of appreciation to the people of my country, who proved day after day that Egypt will never cease to raise new generations of loyal citizens. People of Egypt, I salute your patriotism; you heeded the call of the homeland and were able to finance this formidable accomplishment within a few days. Let us dedicate this wonderful achievement to the souls of Egypt's fallen heroes. We tell them now: you did not make your sacrifice in vain and your defense of your country and people not only protected the homeland, but will also inspire future generations, who will learn from your experience the meaning of redemption, sacrifice and altruism. May you all rest in the peace of heaven.

I owe my gratitude and appreciation to all those who contributed with their creative ideas and hard work to this amazing achievement.

Your Majesties, Excellencies and Highnesses

Ladies and Gentlemen

Dear Guests of Egypt 
The opening of the New Suez Canal to maritime traffic on such an unprecedented accelerated timetable has an impact that goes beyond political and economic goals. It underscores the humanitarian dimension to which the Egypt of the future aspires; one where dignity, justice and stability are realized in a modern, democratic, civil state by mobilizing the ability of the Egyptian people to build at a fast pace in a number of areas.

The current phase of development requires creating an atmosphere conducive to work and investment. The men of the armed forces and police have been serving faithfully and diligently on Egypt's front line in a confrontation with blind, mindless terrorism, which harbors evil, means the people of Egypt harm and wants to impose regressive ideas on them. However, the will and determination of the Egyptian people to defeat and eradicate the terrorists has proved stronger than their violence and malice.

History will judge that the Suez Canal was the springboard from which Egypt's cultural and civilizational influence radiated throughout the region and the world beyond, acting as a link to its disparate corners, dating back to the pharaonic era through the Greek rule and Islamic period and into modern history up until the inauguration of our new canal. Egypt will always remain the meeting point that brings East and West together, a role it has always served throughout its history.

Your Majesties, Excellencies and Highnesses

Ladies and Gentlemen..

\section{Dear Guests}

The great people of Egypt announce to the world today the message of the New Suez Canal: that we triumph over terrorism with life and over hatred with love. Let the canal be a source of prosperity for humanity, not only through its waters but along its banks in keeping with the history of the canal which has left its mark on the map of humanity. Let me make clear that Egypt is not and will never be a one-project nation. As our young population seeks work, it is also capable of creativity and accomplishment. The inauguration of the new canal today is just the first in a number of national projects. Most closely associated with today's achievement is the Suez Canal Area Development Project, of which the general outline has now been approved. The government will immediately start its implementation by developing the East Port Said area, including the expansion and development of East Port Said harbor and the industrial area around it. In addition, we will upgrade the area's infrastructure and link it to other projects underway. Immediately following this, we will develop Ismailia, Al-Qantarah and Ain Sokhna. The development of the canal area entails the establishment of an international economic zone encompassing a number of ports, new cities and logistical and trading hubs that will increase commerce between Egypt and the world. As we continue to realize this goal, we hope our friends from all over the world will join us in our ambitious dream to build the future of Egypt. A number of projects will be launched that focus on constructing a massive national road network, developing the agricultural sector with the reclamation of one million feddans and building a number of new cities to accommodate population growth. In addition, work will begin on a number of new 
ports and industrial development expanded by promoting small and medium-sized enterprises. I assure you all that the Egyptian State renews its determination to pursue the path of political and social reform so as to realize the aspirations of its people for social justice and dignity.

\section{Ladies and Gentlemen,}

I salute you and offer my appreciation, thanking God Almighty for helping us realize this ambitious dream that spurred us to strive for more achievements for our dear beloved Egypt. This great homeland, which entrusted me with the responsibility of leading it, deserves that we do more for it and make sacrifices in order for it to reach its potential. This homeland demands from us pure intentions, diligence at work and adherence to principles and values... all of us, young and old, men and women, Muslims and Christians.

Egypt, which has restored its will with the January 25 and June 30 revolutions, has chosen its path and illuminated its way forward. Although it has not yet accomplished all it has set out to do, it knows what it wants and is moving forward to realize it. If peoples have the ability to dream, then only free people have the ability to achieve. "In the name of God, the Most Gracious, the Most Merciful". By the blessings of God, I, Abdel Fattah El Sisi, the President of the Arab Republic of Egypt, officially open the New Suez Canal"

Long Live Egypt ..Long Live Egypt..Long Live Egypt

Long Live the peace-loving nations around the globe

Long Live the principles of humanity and the values of tolerance and co-existence

Thank You 